\title{
Influence of Energy-Saving Technological Changes on the Level of Innovativeness of Agro-Industrial Enterprises in the Conditions of Digitalization
}

\author{
Ihor Petrushka, Olexandr Yemelyanov, Tetyana Petrushka, Orest Koleshchuk
}

\begin{abstract}
The development and implementation of innovations at enterprises should ultimately ensure the growth of their profit at the expense of transition to the manufacturing of new or improved products, changes in technological processes, sales promotion, etc. In particular, an important reserve for increasing the profits of enterprises is the implementation of innovative resource-saving technological changes, first of all, technologies that provide for the saving of energy resources.

At the same time, the question of how significant is the role that energy-saving technological changes play or can play in the future among other areas of innovative activity of enterprises arises. In other words, the problem arises of assessing the impact of energy-saving technological changes on the level of innovation of enterprises, and, accordingly, on their profitability.

The main purpose of this study is to assess the impact of energy-saving technological changes on the level of innovativeness of agro-industrial enterprises in the conditions of digitalization. The indicators of evaluation of the innovativeness of enterprises are systematized. The indicators characterizing the influence of the innovative activity of the enterprise on the economic efficiency of its functioning are proposed.
\end{abstract}

Keywords: energy-saving technological change, agro-industrial enterprise, innovativeness, profit, profitability, digitalization

\section{INTRODUCTION}

Among the types of economic activities that have a significant impact on the formation of national income and the pace of economic development in many countries of the world are the production and processing of agricultural products. Global production of these products is limited and there is a general tendency to increase demand for it. Therefore, there is an additional potential for economic growth in those countries in which the conditions for the making and processing of agricultural products are the most favorable. In particular, Ukraine is among these countries. However, on the way of development of agro-industrial

Revised Version Manuscript Received on October 15, 2019.

Ihor Petrushka, the Department of Environmental Safety and Nature Protection Activity, Lviv Polytechnic National University, Lviv, Ukraine. Email: petim@ukr.net

Olexandr Yemelyanov, the Department of Business Economics and Investments, Lviv Polytechnic National University, Lviv, Ukraine. Email: oleksandr.y.yemelianov@lpnu.ua

Tetyana Petrushka, the Department of Business Economics and Investments, Lviv Polytechnic National University, Lviv, Ukraine. Email: petrushkat24@ukr.net

Orest Koleshchuk*, the Department of Business Economics and Investments, Lviv Polytechnic National University, Lviv, Ukraine. Email: orest.y.koleshchuk@1pnu.ua businesses in Ukraine exist certain obstacles, among which, in particular, it is possible to emphasize the insufficient level of innovativeness of many Ukrainian agro-industrial enterprises. The impact of innovation of any enterprises on the potential of their economic growth is due to the complex mechanism of the relationship between the volume of innovation, the level of competitiveness and the profitability of enterprises. The development and implementation of innovations in enterprises should ultimately ensure the growth of their profits through the transition to the manufacture of new or improved products, changes in technological processes, sales promotion tools, etc. Especially, an important reserve for increasing the profits of enterprises is the implementation of innovative resource-saving technological changes, first of all, technologies that provide the saving of energy resources.

At the same time, the question of how significant is the role that energy-saving technological changes play or can play in the future among other areas of innovative activity of enterprises. In other words, the problem arises of assessing the impact of energy-saving technological changes on the level of innovation of enterprises, and, accordingly, on their profitability. This task is especially relevant for the case of agro-industrial enterprises of Ukraine, many of which are characterized by a sufficiently high energy intensity of their products in comparison with foreign analogs.

It should also be noted that the realization of innovative energy-saving technological changes at agro-industrial enterprises usually requires significant investment costs. Therefore, a reasonable assessment of the feasibility of such production is important, which requires the acquisition and processing of a significant amount of information necessary for this process. In this regard, it is important to take into account modern means of improving the information support of the processes of development, adoption, and implementation of investment decisions at enterprises, in particular, the possibility of using the means of digitalization for this purpose. 


\section{LITERATURE REVIEW}

In the conditions of increasing competition in many commodity markets, in particular, the markets of agro-industrial products, achieving the appropriate level of economic efficiency of economic activity requires enterprises to ensure their competitiveness [1]. Given the extremely important role that innovation plays in achieving competitive advantages by enterprises, improving the competitiveness of the firm requires the development of sound innovation strategies [2], in particular, strategies for technological change $[3,4]$. Currently, in many countries of the world, technological changes are the determining factor of economic growth $[5,6]$. Among technological changes that are made at the enterprises, it is necessary to emphasize resource-saving technological changes in which the main purpose is the increase of efficiency of use of the corresponding production resources of the enterprises $[7,8]$. In particular, in modern economic conditions of many countries the processes of labor-saving [9] and energy-saving [10] technological changes are intensified. Along with it, information, financial and other barriers appear on the way of technological changes $[11,12]$, the removal of which can give a powerful impulse to accelerate the processes of technological renewal.

The realization of technological changes, especially changes providing the reduction of specific expenses of energy resources, has an essential influence on the majority of parameters of functioning of the enterprises. In particular, it concerns such property of the enterprises as their innovativeness. It should be noted that a number of scientific papers, in particular [13,14], are devoted to the assessment of the innovative activity of enterprises. However, the mechanism of influence of energy-saving technological changes on the level of innovativeness of firms is currently not sufficiently investigated.

\section{FORMULATION OF RESEARCH OBJECTIVES}

The main purpose of this study is to assess the impact of energy-saving technological changes on the level of innovativeness of agricultural enterprises in the conditions of digitalization. To achieve this goal have been determined following tasks: indicators assessment of innovativeness of enterprises was systematized; the indicators characterizing the impact of innovative activity of enterprises on economic performance of its functionality was proposed; a methodological approach to assessing the impact of energy-saving technological change on the level of innovativeness of the enterprise was substantiated; this approach on the example of agricultural enterprises of Ukraine was implemented.

\section{PRESENTATION OF THE MAIN RESEARCH MATERIAL}

The concept of enterprise innovativeness is complex and multifaceted. This necessitates the use of a multi-indicator approach to assessing the level of innovativeness of firms. According to this approach, the assessment is carried out using not one, but a number of indicators. At the same time, it seems expedient to divide the indicators by which the level of innovativeness of the enterprise is estimated into such groups:
1) indicators characterizing the volume of innovative activity of the enterprise for a certain period of time. These indicators should primarily include the following: the total number of innovations developed by the company during the reporting period; the number of innovations developed by the company during the reporting period, by type (food, technical, marketing, etc.); total number of changes introduced by the enterprise during the reporting period; number of innovations implemented by the enterprise during the reporting period, by type; volume of investments made by the company in the development of innovations; volume of investments made by the company in the introduction of innovations; the share of investments made by the company in the development and implementation of innovations in the total amount of incurred investment expenses in the reporting period; cost volume of production enterprise of innovative products in the reporting period; cost volume of sales by an enterprise of innovative products in the reporting period; the proportion of the value of production of the enterprise of innovative products in the reporting period in the total value of manufactured products during this period; the share of value sales by company for innovative products in the reporting period in the total monetary volume of sold products in this period; the number of patents for objects of industrial property, received by the company during the reporting period; the number of licenses issued by the company to use the owned objects of industrial property;

2) indicators characterizing the volume and quality of innovative resources of the enterprise. Among others, these indicators include: the initial cost of the enterprises fixed assets, which are involved in the development and implementation of innovations; the area of research laboratories of enterprises, number of employees involved in the development and implementation of innovations; the level of the technical state of the enterprises fixed assets, which are involved in the development and implementation of innovations; the level of qualification of employees involved in the development and implementation of innovations;

3) indicators of the level of novelty of innovations developed and implemented at the enterprise. This level can be estimated, using the methodology of the expert survey and the use of such quantitative indicators as the ratio of prices of improved and old products; the ratio of unit costs of resources for new and old resource-saving technologies of production; the ratio of specific profit from the production and sale of improved and old product; the ratio of specific profit from the production and marketing of products manufactured by innovative resource-saving technologies, and of the same products subject to the production of it using the old resource-intensive technologies;

4) indicators characterizing the impact of innovative activities of the enterprise on the economic efficiency of its operation. In particular, it is reasonable to use such indicators for this purpose: 
- indicator of the share of profit of the enterprise from the implementation of its innovative activities in the total value of its operating profit in the reporting period:

$$
I_{1}=1-\frac{P_{n i}}{P}
$$

where: $I_{1}-$ indicator of the share of enterprise profit from implementation of innovative activities in the total amount of its operating profit in the reporting period, shares of unit ; $P_{n i}$ - value operating profit (loss) of the company in the reporting period which would be received by the company, if it generally did not implement innovation activity, monetary units; $P$ - the actual value of the operating profits of the enterprise in the reporting period, monetary units;

- an indicator of the relative growth of the profitability capital of the enterprise on its operating profit as a result of innovative activities:

$$
I_{2}=1-\frac{P_{a n i}}{P_{a}}
$$

where: $I_{2}$ is the indicator of the relative profitability of the capital of the company by its operating profit through the implementation of innovative activities, the share of units; $P_{a n i}-$ level of profitability (loss) capital in the reporting period, which the company would have, if it generally did not implement innovation, shares of unit; $P_{a}$ - the actual rate of profitability of capital of the company by its operating income in the reporting period, the share units;

5) indicators characterizing the impact of innovative activity of the enterprise on its competitive advantages. In particular, these indicators could include the following: the ratio of prices for innovative products of the investigated company and similar companies ' products - its competitors; the ratio of the specific cost of resources in the new resource-saving technologies of production, which introduced the investigated enterprise, and unit costs of these resources to similar products from competitors; the ratio of specific profit from the production and sale of innovative products of the investigated enterprises from the production and sales of similar products from its competitors; the ratio of specific profit from the production and distribution of products, which is made of the investigated enterprise with innovation resource-saving technology, and specific profits from the production and sale of the same products from competitors.

It should be noted that the calculation of the $P_{n i}$ indicator in formula (1) requires the accounting of the following four components in the operating profit of the enterprise: profit due to the production and sale of products that are innovative, however, manufactured using traditional technologies( machinery, materials); profit due to the production and sale of products that are innovative and manufactured using innovative technologies; profit due to the production and sale of products that are not innovative, but manufactured using innovative technologies; additional profit derived from the introduction of other types of innovations by the enterprise (marketing, organizational, etc.). Under such conditions, the value of the $P_{n i}$ indicator in formula (1) will be defined as the difference between the actual operating profit of the enterprise and the sum of the four components of this profit

\section{listed above.}

In reference to the $P_{a n i}$ in formula (2), during the calculation, one should take into account the possibility of changes in the total capital of the enterprise due to the making of the corresponding investment costs for the development and implementation of innovations. Especially, this applies to investments in the acquisition of new equipment by the enterprise.

It should also be noted that if the investigated enterprise is profitable, the values of indicators (1) and (2) cannot be negative. At the same time, the zero value of these indicators is possible only if the enterprise does not carry out innovative activities and, accordingly, it has a lack of innovativeness. Therefore, the higher the value of indicators (1) and (2), the higher the level of innovativeness of the enterprise.

The use of indicators (1) and (2) also allows assessing the impact of energy-saving technological changes on the level of innovation of enterprises. To this end, these indicators should be calculated twice: respectively, taking into account and without taking into account the use of energy-saving technologies by the enterprise (of course, if such an application actually occurs). In turn, the increase in operating profit of the enterprise as a result of the introduction of energy-saving technological processes can be calculated using this formula:

$$
\Delta P_{e}=\sum_{i=1}^{n} \sum_{j=1}^{m} Q_{i} \cdot p_{r e j}\left(c_{b i j}-c_{n i j}\right)+\sum_{i=1}^{n} \Delta Q_{i} \cdot p_{n i}-C
$$

where: $\Delta P_{e}$ is the increase in the operating profits of the enterprise as a result of introducing them to energy-saving technological processes, monetary units; $n$ - number of types of products produced by the enterprise; $m$ - number of types of energy resources which the company uses in its operating activities and which the company in the previous periods have been energy-saving technological changes; $Q_{i}$ is the physical volume of production of enterprise $i$ in product (excluding the increase in these volumes due to the increase of competitiveness of the enterprise, caused, in turn, reducing the unit costs through the production of energy-saving technological change); $p_{r e j}$ - average during the reporting period, the purchase unit price of the j-th energy resources, monetary units; $c_{b i j}, c_{n i j}$ - the physical cost of $j$-energy resource per unit of the $i$-product, accordingly before and after the implementation of the enterprise energy-saving technological change; $\Delta Q_{i}$ is the increase in physical volume of production of enterprise $i$-product caused by the reduction of unit costs through the production of energy-saving technological change; $p_{n i}-$ specific profits from the production and sales of the $i$-product in the reporting period, monetary units; $C$ - the value of other types of operating costs of the company related to the enterprise energy-saving technological change (in particular, costs associated with the possible substitution of some other energy resources), monetary units.

Taking into account formula (3), indicators for assessing the impact of energy-saving technological changes on the level of innovativeness of enterprises can be formalized in this way: 


$$
\begin{gathered}
Z_{1}=I_{1}-I_{1 e} \\
Z_{2}=I_{2}-I_{2 e}
\end{gathered}
$$

where: $Z_{l}$ is the impact assessment indicator of energy-saving technological changes on the level of innovativeness of enterprises by size of its operating profit, share of units; $I_{l e}$ - the share of enterprise profit from implementation of innovative activities in the total amount of its operating profit in the reporting period, excluding profit from the implementation of energy-saving technological change, share of units; $Z_{2}$ - impact assessment indicator of the energy-saving technological change on the level of innovativeness of the enterprise by the amount of profit of its capital, shares of unit; $I_{2 e}-$ a measure of the relative profitability of the capital of the company by its operating profit through the implementation of innovative activities excluding profit and investment costs, due to the implementation of energy-saving technological change, the fraction of a unit.

In particular, the indicator $I_{l e}$ in equation (4) can be calculated by the formula:

$$
I_{1 e}=1-\frac{P_{n i}}{P-\Delta P_{e}}
$$

Accordingly, the indicator (4) will be determined by the formula:

$$
Z_{2}=I_{2}-I_{2 e}=1-\frac{P_{n i}}{P}-\left(1-\frac{P_{n i}}{P-\Delta P_{e}}\right)=\frac{P_{n i}}{P-\Delta P_{e}}-\frac{P_{n i}}{P}
$$

We will test the proposed methodological approach to assessing the impact of energy-saving technological changes on the level of innovativeness of the company on the example of agro-industrial enterprises of Ukraine. To this end, we have collected information on the activities of forty enterprises of such type, which belong to four types of economic activities, namely: horticulture, animal husbandry, processing of crop products and processing of livestock products (Table-I). All of these businesses were profitable in 2018. At the same time, some of them carried out energy-saving technological changes during 2013-2017.

Using formulas (4), (6) and (7), we calculate the indicators of innovativeness of the investigated agro-industrial enterprises by their operating income, as well as assess the

\begin{tabular}{|c|c|c|c|c|c|}
\hline \multirow[b]{2}{*}{ Indicators } & \multicolumn{5}{|c|}{ Values of indicators by types of economic activity } \\
\hline & Horticulture & $\begin{array}{l}\text { Animal } \\
\text { husbandry }\end{array}$ & $\begin{array}{l}\text { Processing of crop } \\
\text { products }\end{array}$ & $\begin{array}{l}\text { Processing of } \\
\text { livestock products }\end{array}$ & Total \\
\hline $\begin{array}{l}\text { 1. Number of enterprises under } \\
\text { investigation }\end{array}$ & 14 & 8 & 11 & 7 & 40 \\
\hline $\begin{array}{l}\text { 2. Number of enterprises that implemented } \\
\text { energy-saving technological changes } \\
\text { during 2013-2017 }\end{array}$ & 5 & 3 & 8 & 3 & 19 \\
\hline $\begin{array}{l}\text { 3. Total operating profit in } 2018 \text {, thousand } \\
\text { US dollars }\end{array}$ & 635 & 381 & 560 & 279 & 1855 \\
\hline \multicolumn{6}{|l|}{ Including: } \\
\hline $\begin{array}{l}\text { 3.1. Enterprises that implemented } \\
\text { energy-saving technological changes }\end{array}$ & 406 & 257 & 486 & 182 & 1331 \\
\hline $\begin{array}{l}\text { 3.2. Enterprises that have not carried out } \\
\text { energy-saving technological changes }\end{array}$ & 229 & 124 & 74 & 97 & 524 \\
\hline
\end{tabular}
impact of energy-saving technological changes on the level of innovativeness of these enterprises (Table-II.).

Table - I: Initial information on individual indicators of agro-industrial enterprises activity in Ukraine

As follows from the data that is provided in table 2, the average level of innovativeness of the investigated agro-industrial enterprises by their operating income ranges from 0.246 for horticulture to 0.527 for processing of products. Thus for all types of economic activity enterprises that carried out energy-saving technological changes considerably (on average more than twice) exceeds the level of innovativeness of the enterprises which did not conduct energy-saving technological changes. It should also be pointed out that there is a strong influence of energy-saving technological changes on the level of innovativeness of the investigated enterprises in terms of their operating profit. In particular, the average level of innovativeness of the investigated enterprises that have plemented energy-saving technologies is 0.484. At the time, the average value of the indicator for these conditioned by this production.

Regarding the investigated agro-industrial enterprises, we conducted a survey on the presence of obstacles during the implementation of this kind of realization. The results of the same time.

1. From the data provided in table 3, it follows that according to the managers of the investigated agro-industrial enterprises, the main obstacle to the realization of nergy-saving technological changes is the lack of necessary (this obstacle was noted by $61.9 \%$ of (he obstacle Ukraine. In particular, it concerns the creation of datass on manufacturers and consumers of energy-saving equipment, as well as indicators on the basis of which the economic efficiency of investment projects for the purchase of such equipment is estimated. 


\begin{tabular}{|l|l|l|l|l|}
\hline $\begin{array}{l}\text { 4. The amount of operating profit due to } \\
\text { innovative activities, thousands of US } \\
\text { dollars. }\end{array}$ & 188 & 146 & 237 & 193 \\
\hline Including: & & & 764 \\
\hline $\begin{array}{l}4.1 . \quad \text { Enterprises that implemented } \\
\text { energy-saving technological changes }\end{array}$ & 156 & 123 & 218 & 147 \\
\hline $\begin{array}{l}4.2 . \text { Enterprises that have not carried out } \\
\text { energy-saving technological changes }\end{array}$ & 32 & 23 & 19 & 46 \\
\hline $\begin{array}{l}\text { 5. The amount of operating profit due to } \\
\text { energy-saving technological changes, } \\
\text { thousands of US dollars. }\end{array}$ & 134 & 101 & 166 & 119 \\
\hline
\end{tabular}

Table- II: Indicators of innovativeness of agro-industrial enterprises and the results of assessing the impact of energy-saving technological changes on the level of innovativeness of these enterprises

\begin{tabular}{|c|c|c|c|c|c|}
\hline \multirow[b]{2}{*}{ Indicators } & \multicolumn{5}{|c|}{ Values of indicators by types of economic activity } \\
\hline & Horticulture & $\begin{array}{l}\text { Animal } \\
\text { husbandry }\end{array}$ & $\begin{array}{l}\text { Processing of crop } \\
\text { products }\end{array}$ & $\begin{array}{l}\text { Processing of } \\
\text { livestock products }\end{array}$ & Total \\
\hline $\begin{array}{l}\text { 1. Average level of innovativeness of } \\
\text { enterprises by their operating income, } \\
\text { share of unit }\end{array}$ & 0,246 & 0,323 & 0,389 & 0,527 & 0,347 \\
\hline \multicolumn{6}{|l|}{ Including: } \\
\hline $\begin{array}{l}\text { 1.1. Enterprises that implemented } \\
\text { energy-saving technological changes }\end{array}$ & 0,384 & 0,479 & 0,449 & 0,808 & 0,484 \\
\hline $\begin{array}{l}\text { 1.2. Enterprises that have not carried out } \\
\text { energy-saving technological changes }\end{array}$ & 0,140 & 0,185 & 0,257 & 0,474 & 0,229 \\
\hline $\begin{array}{l}\text { 2. Indicator for assessing the impact of } \\
\text { energy-saving technological changes on } \\
\text { the level of innovation of the enterprise in } \\
\text { terms of its operating profit, unit share }\end{array}$ & 0,303 & 0,338 & 0,286 & 0,363 & 0,331 \\
\hline
\end{tabular}

Table- III: The results of the survey of managers of the investigated agro-industrial enterprises, which did not carry out energy-saving technological changes, regarding the obstacles for this kind of realization

\begin{tabular}{|l|l|l|l|l|l|}
\hline \multirow{2}{*}{ Indicators } & Values of indicators by types of economic activity & \multicolumn{2}{|c|}{} \\
\cline { 2 - 6 } & Horticulture & $\begin{array}{l}\text { Animal } \\
\text { husbandry }\end{array}$ & $\begin{array}{l}\text { Processing of crop } \\
\text { products }\end{array}$ & $\begin{array}{l}\text { Processing } \\
\text { livestock products }\end{array}$ & Total \\
\hline $\begin{array}{l}\text { 1. Number of enterprises that have not } \\
\text { carried out energy-saving technological } \\
\text { changes }\end{array}$ & 9 & 5 & 3 & 4 & 21 \\
\hline $\begin{array}{l}\text { 2. The number of enterprises whose } \\
\text { managers among the obstacles to the } \\
\text { implementation of energy-saving } \\
\text { technological changes denominated: }\end{array}$ & & & & & \\
\hline $\begin{array}{l}\text { 2.1. Lack of necessary information for the } \\
\text { realization of energy-saving technological } \\
\text { changes }\end{array}$ & 6 & 3 & 2 & 2 & 13 \\
\hline $\begin{array}{l}\text { 2.2. The lack of financial resources for the } \\
\text { realization of energy-saving technological } \\
\text { change }\end{array}$ & 4 & 2 & 1 & 2 & 9 \\
\hline $\begin{array}{l}\text { 2.3. Other obstacles (especially, } \\
\text { insufficient efficiency of energy-saving } \\
\text { technological change projects from the } \\
\text { point of view of managers) }\end{array}$ & 3 & 1 & 1 & 1 \\
\hline $\begin{array}{l}3 . \text { The share of enterprises, whose } \\
\text { managers called the lack of information } \\
\text { one of the obstacles to the realization of } \\
\text { energy-saving technological changes, in } \\
\text { percentage }\end{array}$ & 66,67 & 60,00 & 66,67 & & 6 \\
\hline
\end{tabular}

\section{CONCLUSION}

It is reasonable to emphasise five groups of indicators which assess the level of innovativeness of the enterprise, namely: indicators of the volume of innovative activity of the enterprise for a certain period of time; indicators of the amount and quality of innovation resources of the enterprise; indicators of the level of novelty of developed and implemented at the enterprise innovations; indicators of the impact of innovative activity on its economic performance; indicators of the impact of innovative activity of enterprise on its competitive advantages. Among these groups of indicators to assess the impact of energy-saving technological changes on the level of innovativeness of enterprises, first of all, the indicators of the fourth group of them all should be implemented. To this end, these indicators should be calculated twice: respectively, taking into account and without taking into account the use of energy-saving technologies by the enterprise. At the same time, as shown by

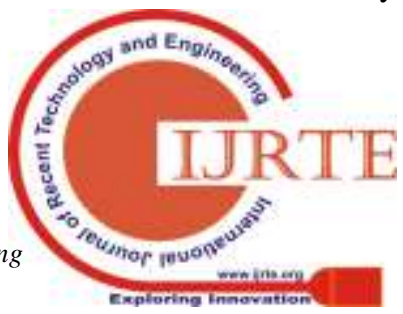


the study of the totality of agro-industrial enterprises of Ukraine, which introduced energy-saving technologies, about $68 \%$ of the level of innovativeness of these enterprises are conditioned by this realization. It was also revealed that, according to the managers of the investigated agro-industrial enterprises, the main obstacle to the realization of energy-saving technological changes is the lack of necessary information. One of the means of overcoming this obstacle is the digitalization of agricultural business in Ukraine.

\section{REFERENCES}

1 Sieradzka, K., and Luft, R. (2015). Theoretical Aspects of Enterprise Competitiveness. Central European Review of Economics \& Finance. 2015, 10 (4), 133-141.

2 Karlsson, C., and Tavassoli, S. (2016). Innovation strategies of firms: What strategies and why? The Journal of Technology Transfer, 4 (6), 1483-1506.

3 Obradovic, D., and Ebersold, Z. (2015). Role of technology strategy in competitiveness increasing. Economic Annals-XXI, 1-2(1), 32-35.

4 Mrykhina, O. B., Stoianovskyi, A. R., and Mirkunova, T. I. (2015). Startup companies perspectives in the context of competitive development of Ukrainian high technologies market. Actual Problems of Economics, 171(9), 215-225.

5 Caliscan, H. K. (2015). Technological change and economic growth. Procedia Soc. Behav. Sci., 195, 649-654.

6 Sredojecic, D., Cvetanovic, S., and Boskovic, G. (2016). Technological changes in economic growth theory: neoclassical, endogenous, and evolutionary-institutional approach. Economic Themes, 54(2), 177-194.

7 Rohn, H., Pastewski, N., Lettenmeier, M., Wiesen, K., and Bienge, K. (2014). Resource efficiency potential of selected technologies, products and strategies. Science of The Total Environment. 2014, 473-474, 32-35.

8 Lesinskyi, V., Yemelyanov, O., Zarytska, O., Symak, A. and Koleshchuk, O. (2018). Substantiation of projects that account for risk in the resource-saving technological changes at enterprises. Eastern-European Journal of Enterprise Technologies, 6 (1), 6-16.

9 Piva, M., and Vivarelli, M. (2018). Technological change and employment: is Europe ready for the challenge. Eurasian. Bus. Rev., 8(1), 13-32.

10 Jin, L., Duan, K., and Tang, X. (2018). What Is the Relationship between Technological Innovation and Energy Consumption? Empirical Analysis Based on Provincial Panel Data from China. Sustainability, 10, 145.

11 Trianni, A., Cagno, E., Worrell, E., and Pugliese, G. (2013). Empirical investigation of energy efficiency barriers in Italian manufacturing SMEs. Energy, 49, 444-458.

12 Kostka, G., Moslener, U., and Andreas, J. (2013). Barriers to increasing energy efficiency: evidence from small-and medium-sized enterprises in China. J. Clean. Prod., 57, $59-68$.

13 Tian, M., and Zhang, M. A Review of the Relationship between Technological Innovation and Enterprise Value. Advances in Engineering Research, 113, 606-610.

14 Valitov, Sh. M., and Khakimov, A. Kh. (2015). Innovative Potential as a Framework of Innovative Strategy for Enterprise Development. Procedia Economics and Finance, 24, 716 - 721

\section{AUTHORS PROFILE}

Ihor Petrushka - Professor, Doctor of Technical Sciences, is the Head of the Department of Environmental Safety and Nature Protection Activity at Lviv Polytechnic National University. In 2016 he became a member of the editorial board of the "Environmental Problems" scientific journal. From 2013, according to the resolution of the Cabinet of Ministers of Ukraine of 9.08.2001 No. 978 “On Approval of the Regulation on the Accreditation of Higher Educational Institutions and Specialties in Higher Educational Institutions", Professor I. Petrushka was repeatedly appointed to be an expert conducting the accreditation examination of Masters' training in higher educational institutions of Ukraine. Consequently the sphere of scientific interests of Professor Ihor Petrushka is associated with the development and improvement of environmentally safe technologies. This is a promising and relevant direction of scientific research, especially if one considers the goals of sustainable development and takes into account the problems of the development of science in particular.

The results of the scientific work include over 210 scientific papers, reports and presentations at more than 100 international scientific conferences, publication of 3 textbooks, 2 manuals and 5 monographs.

ORCID iD: https://orcid.org/0000-0002-9009-8341

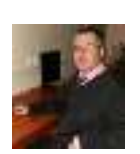

Olexandr Yemelyanov - PhD (Economics), Associate Professor of the Department of Enterprise Economics and Investment at the Institute of Economics and Management of Lviv Polytechnic National University. He has published more than 120 scientific and methodological works. The main area of scientific interest is assessment of the economic potential the enterprise. Yemelyanov O. participates in the research work of the department, manages the execution of the contractual topics. Basic research is related to enterprise management, innovative capacity assessment and competitiveness.

Yemelyanov O. teaches the subjects "Innovative development of Enterprise", "Enterprise Economics", "Economics and organization of enterprise innovation activity", and others. Supervises the implementation of qualification work by students of the department. Participates in the preparation of student research projects and conferences.

\section{ORCID iD: https://orcid.org/0000-0002-1743-1646}

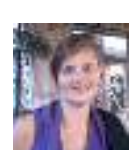

Tetyana Petrushka - PhD (Economics), Associate Professor of the Department of Enterprise Economics and Investment at the Institute of Economics and Management of Lviv Polytechnic National University. She has published more than 80 scientific and methodological works. The main direction of the scientific interests of Petrushka T. is resource-saving and resource-saving technologies in the enterprise. Petrushka T. teaches the subjects "Organization of production", "Construction Economics, Fundamentals of Management and Marketing", and others. Participates in the preparation of student research projects and conferences. She is responsible for the entry of students to the Master's degree level in Economics. Petrushka T. engages in the practice management and organization of excursions for students in order to familiarize them with the production process at the enterprise.

\section{ORCID iD: https://orcid.org/0000-0002-2005-5573}

Orest Koleshchuk - PhD (Economics), Associate Professor of the Department of Enterprise Economics and Investment at the Institute of Economics and Management of Lviv Polytechnic National University. $\mathrm{He}$ has published more than 40 scientific and methodological works. The main area of scientific interes is technology transfer, innovation and innovative susceptibility. Koleschuk O. participates in the research work of the department, manages the execution of the contractual topics. Basic research is related to enterprise innovation management, innovative capacity assessment and susceptibility.

Koleschuk O. teaches the subjects "Economics and Management of Enterprise", "Enterprise Economics", "Fundamentals of Entrepreneurship", "Construction Economics, Fundamentals of Management and Marketing", and others. Supervises the implementation of qualification work by students of the department. Participates in the preparation of student research projects and conferences.

ORCID iD: https://orcid.org/0000-0001-8995-5206 